\title{
DIVERSIFICATION AND FIRM PERFORMANCE IN AN EMERGING MARKET: THE TURKISH CASE
}

\author{
Arman T. TEVFÍK \\ Fuat OKTAY \\ Beykent University, Istanbul.
}

\begin{abstract}
Decision makers frequently utilize diversification as a strategic option to improve organizational performance. Researchers intensively studied to figure out the relationship between the diversification and organizational performance (Pandya and Rao 1998;67-81, Lubatkin et al. 1989;454-465, Rumelt 1982;359-369). While the general acceptance is that the less diversified firms perform better than the highly diversified ones for the developed countries or markets, it is believed that the diversified firms would perform better in emerging markets (Pandya and Rao 1998; 67-81, Rumelt 1982;359-369). This research delves into Turkey as an emerging market, and tests to see whether the above hypothesis on the emerging markets holds true for Turkish case. Contrary to the findings of the literature on the emerging markets, the results suggest that less diversified firms perform better than the highly diversified ones in Turkey, as in the case of developed markets and/or western economies. The authors question whether this might be an early signal of structural change in Turkish market.
\end{abstract}

Key Words: Diversification Strategies, Concentric Diversification, Conglomerate Diversification, Firm Performance, Emerging Markets

\section{INTRODUCTION}

Diversification is defined as a firm's entry into new markets or industries with new products or new lines of activities (Ramanujan and Varadarajan 1989;523551). In addition to carrying the risk of having all the firm's eggs in one industry basket, there is no urgent need to diversify for a company as long as the profitable growth opportunities exist in its current industry. Firms follow either vertical or horizontal growth strategies within an industry until it reaches to maturity. Shifts in buyer preferences, slowing or diminishing demand for the industry products, becoming competitively unattractive or unprofitable, increase in substitute products, increase in innovation of alternative technologies, limited opportunities in the existing business, etc., are some of the signs for a firm to look into alternative growth strategies. To continue growing at the maturity stage, the firms might try to expand internationally into less mature markets. In case they would not, firms might need to diversify into different industries. Concentric and conglomerate diversifications are the two diversification strategies that they may follow (Wheelen and Hunger, 2007; 164-171, Thompson et al. 2007; 269-299).

Entering unrelated areas or industries is referred to as the conglomerate diversification through which corporations aim to reduce the overall risk exposure and expand growth opportunities. Related diversification, on the other hand, refers to expanding beyond the existing product lines and/or market of the current industry (Wheelen and Hunger 2006; 164171 , Eren 2005; 221-232). Related diversification is believed to lower the profitability rate in developed countries or economies.

Focusing on core competencies are suggested over the conglomerates for the western economies. Literature unreveals that firms pursuing unrelated strategies tend to face with lower profitability and higher levels of risk exposure than the ones following other types of corporate-level growth strategies (Harrison 2002, Khanna and Palepu 1997). While focusing strategies are suggested for the west, conglomerates still provide certain advantages for emerging markets which have institutional and structural shortcomings (Pandya and Rao 1998; 6781). The related literature is reviewed to lay down the research hypothesis. Research methodology, including the sample collection procedures, research variables, and data analysis methods, is presented in the following sections. 


\section{REVIEW OF RELATED LITERATURE}

Palich et al. (2000; 155-174) discusses three factors for a mature research field as (i) substantial number of empirical studies, (ii) consistent and cohesive findings of those empirical studies, and (iii) general consensus on the nature of the major relationships in the field (Palich et al. 2000; 155-174). Alhorr (2005) argues that the field of diversification has not reached to maturity yet due to the lack of consistent and cohesive findings and general consensus.

Strategic Management researchers tend to agree upon the existence of relationship between diversification and organizational performance (Markides 1990; 398412). However, they have no general consensus on the nature of the relationship (Alhorr 2005). Some studies reached to similar conclusions regarding the impact of diversification on firm performance as: (i) inconclusive empirical evidence, (ii) having different models, perspectives and results based on the different disciplinary perspective of the researcher, (iii) complex nature of relationship between diversification and organizational performance which is affected by intervening variables, such as concentric versus conglomerate diversification, type of relatedness, industry structure, and the capability of top managers (Datta et al.1981; 529-558, Hoskisson and Hitt 1990; 461-509, Kerin et al. 1990).

Among the research done on the relationship between diversification and organizational performance, some concluded negative relationships (Bettis 1982; 251264, Palepu 1985; 239-255, Rumelt 1982; 359-369, Varaderajan and Ramanujam 1990; 523-551), some suggested positive relationships (Lubatkin 1987; 665684, Michel and Shaked 1984; 18-25, Weston and Mansinglika 1971; 919-936), and some concluded lack of relationship (Grantt et al.1988; 771-801, Montgomary 1985; 789-798). Those findings also support the claim of the lack of consensus about the relationship between the diversification and performance.

Some researchers conclude that less diversified firms perform better than highly diversified firms (Pandya and Rao 1998, Christensen and Montgomery 1981; 327-347, Keats 1990; 61-72, Michel and Shaked 1984; 18-25, Rumelt 1986; 359-369). Rather than diversification per se, Prahalad and Bettis (1986;523552) claim that it is the managers' insight and vision or strategic logic that contributes to the successful diversification. There are other researchers who argue that it is not the management conduct but the industry structure that determines the firm performance (Christensen and Montgomery 1981; 327-347, Montgomery 1985; 789-798).

In addition to the diversification types and industry structure, researchers looked into the effects of mode (internal R\&D versus Mergers and acquisitions) and found out that " $R \& D$ based product development is better than mergers and acquisition-led diversification" (Simmonds 1990; 399-410, Lamont and Anderson 1985; 926-934).

While Normann (1984) suggests service firms not to diversify, Nayyar (1993; 569-591) shows that serviceindustry-diversification, based on "information asymmetry," is positively associated with performance. Nayyar (1993; 569-591) also concluded that diversification-based economies of scope are negatively associated with performance. Nayyar points out the existence of a limit on how much a firm can diversify, and claims that the market value of a firm would suffer if it goes beyond that limit. Lowering the diversification level through refocusing strategy when it reaches or exceeds that point contributes to the value creation of the firm (Markides 1992; 398-412).

The review of the related literature suggests that the relationship between the diversification and organizational performance is complex and is affected by "intervening and contingent" variables (Pandya and Rao 1998; 67-81). Some findings in the literature suggest that stockholders do not "pay a premium for diversified firms" (Brealey and Myers 1996). The market does not value "risk/return trade-off positively for unrelated diversification either (Lubatkin and O’Neil 1987; 665-684). Jahero et al. (1987; 51-62) argue that highly diversified firms perform better regardless of size.

In summary, the findings and arguments presented above seems to suggest that single-product or less diversified firms should perform better than the highly diversified firms in western economies and/or developed markets.

The evidence suggests the other way around for the emerging markets due to the institutional shortcomings and insufficient market conditions. Since the market inefficiency in emerging markets may not follow firms to allocate their resources optimally, the managers might be in a more advantageous position to diversify their product market or industry, and thus, improve firm performance (Pandya and Rao, 1998;67-81). In this study, we want to test the nature of the relationship between the diversification strategies and the 
organizational performance of firms in Turkey as an emerging market, and thus propose the following null hypothesis:

Our null hypothesis $(\mathrm{HO})$ is that: Highly diversified firms perform better than the undiversified firms in Turkey as an emerging market.

Based upon the above-mentioned arguments and findings against the proposed null hypothesis, we state the alternate hypothesis as:

Alternate hypothesis (H1): Less diversified firms perform better compared to diversified firms in Turkey as an emerging market.

\section{RESAERCH DESIGN}

\section{Sampling}

The research is designed to test the effect of diversification on the firms' performances in Turkey as emerging market. The study covers the large-size Turkish firms shares of which are traded in Istanbul Stock Exchange (ISE). A sample of 99, out of 312, ISE-firms are taken into consideration in this study. The year 2005 was chosen to measure the firms' financial performances and the specialization ratios. The original design of this study was to collect data for the last five years. However, it was found out that ISE firms were not required to prepare consolidated financial statements and disclose segmental reporting until the year of 2005 . The data for 2006 has not been released either. Therefore, the only available data for the year 2005 has been utilized for this study. The authors believe that it is beneficial to continue research and test the above stated hypothesis using the available data in the future. The research would be a starting point and the additional data would be integrated into the model as it becomes available. The authors consider the research and the findings as "preliminary," and will continue to develop it.

\section{Variables}

Firm performance is tested mainly as a function of diversification. In other words, diversification is used as the independent variable and the performance is utilized as the dependent variable. Size and industry are included in the model as control variables. Operational definitions of those variables are provided below:

Performance: Organizational performance is frequently measured using accounting based variables, such as return on assets (ROA), return on equity (ROE), and return on sales (ROS). Although accounting-based performance measurements have been criticized in the past, they have recently been defended and utilized by management researchers. (Bromily 1986; Jacobson 1987; 470-478; Long and Ravenscraft 1984; 494501). In this study, we used just one performance measure, ROE (return on equity) which is defined as net income divided by shareholders equity.

Corporate Diversification: Specialization Ratio (SR) is one of the methods used to assess diversification. It explains the weight of the firm's core business activities over the rest of the firm's activities. (Rumelt, 1982; 359-369; Shaikh \& Varadarajan, 1984; 185189). This study utilizes SR to measure how the firm has diversified. Operationally, SR is "a ratio of the firm's annual revenues from its largest discrete, productmarket activity to its total revenues" (Pandya and Rao, $1998 ; 67-81)$. It is relatively easy to understand and calculate. Pandya and Rao use SR to classify firms into three diversification classes, namely, undiversified ( $\mathrm{SR} \geq$ '3f 0.95 ), moderately diversified $(95 \leq$ '3f SR $\geq$ '3f $0.5)$, and highly diversified $(\mathrm{SR}<0.5)$. While they define SR on a three scale variable $(0,1,2$, respectively), we define SR as a continuous variable. SR value of 1 would represent an undiversified firm while SR value of less than one would represent a diversified firm; the lower the SR value the more diversified the firm is. The near-zero SR values would represent highly diversified firms. The advantage of this approach is to get a higher sense of the diversification scale with the limited data available at ISE.

Control Variables: Although a number of variables affect the performance of a company, we have chosen Size and Industry, as the control variables.

Size: Since the research indicates that the larger firms tend to dominate the market, size has been included in the studies of firm diversification and organizational performance (Christensen and Montgomery 1981; 327-347). It is believed that organization size can be a significant intervening variable in profitability. Therefore, it is included as a control variable in this research, and is measured as the natural logarithm of total assets (Baysinger and Hoskisson 1989; 310-312).

Industry: The stock price changes of a firm are strongly correlated with the stock price changes of the overall market. Usually, shares of a certain industry tend to follow a similar pattern. Thus, the related industry in addition to the global and macroeconomic environments- needs to be analyzed to explore more into the stock price changes. In short, return on shares 
is related with the return on stock exchange market and the return on the related industry (King 1966; 139-190). Therefore, industry is taken into account as an intervening variable in our analysis. The firms included in our research are categorized into 12 different industries and coded as discrete measurements, such as $1,2,3, \ldots, 12$.

\section{DATA ANALYSIS AND DISCUSSIONS}

The hypothesis was tested by using the regression analysis. It is used to test the general relationships between the firm's performances (dependent variable) and the measures of diversification for 2005, size, and industry affiliation (sector) included as independent variables.
Majority of earlier studies of diversification used cross sectional data and single measures of performance. Due to lack of data, we have to examine relatively a small sample of firms with data over one year period. We use 99 firms, and one performance measure. Specialization Ratio, as the independent variable, measures the extent of diversification. Asset size and industry affiliation are used as control variables. ROE is our performance variable.

The descriptive statistics of the data show no abnormalities (see Table 1). As shown in correlation matrix (Table 2), the diversification level of the firm (SR) is correlated neither with the size nor the sector affiliation

of the firm. This implies that there exists no multicollinearity among the independent variables (see also VIF values in Table 4). However, the

\begin{tabular}{|l|l|l|l|l|}
\hline \multicolumn{4}{|l|}{ Table 1: Descriptive Statistics } \\
\hline Mean & ROE & SR & Ln Asset & Sector \\
\hline Standard Error & 0.0943 & 0.9290 & 15.6500 & 5.5859 \\
\hline Median & 0.0118 & 0.0159 & 0.2833 & 0.3109 \\
\hline Mode & 0.0945 & 1.0000 & 15.3647 & 6.0000 \\
\hline Standard Deviation & 0.0874 & 1.0000 & 15.8958 & 1.0000 \\
\hline Sample Variance & 0.1170 & 0.1582 & 2.8190 & 3.0938 \\
\hline Range & 0.0137 & 0.0250 & 7.9470 & 9.5716 \\
\hline Minimum & 0.8086 & 0.6536 & 10.0102 & 11.0000 \\
\hline Maximum & -0.4662 & 0.3464 & 11.3912 & 1.0000 \\
\hline Count & 0.3424 & 1.0000 & 21.4014 & 12.0000 \\
\hline Confidence Level (95\%) & 99 & 99 & 99 & 99 \\
\hline
\end{tabular}

independent variables are all correlated with the performance variable, ROE. We regress the performance variable ROE against the predictor variables Size, SR, and the Sector to see the impact of those independent variables upon the firm's performance, and also to test whether the relationships between the firm's performance and each one of those

\section{Table 2: Correlation matrix}

\begin{tabular}{|l|l|l|l|}
\hline & SR & Ln Asset & Sector \\
\hline SR & 1.0000 & & \\
\hline Ln Asset & -0.0832 & 1.0000 & \\
\hline Sector & -0.0684 & -0.0289 & 1.0000 \\
\hline ROE & 0.3318 & 0.2548 & -0.3614 \\
\hline
\end{tabular}

independent variables is statistically significant or not. As provided in the ANOVA table (Table 3), F-value clearly states that the model is statistically significant.

High t-values in absolute terms (Table 4) tell us that coefficients of the independent variables are not zero, meaning that each one of them significantly contributes to the explanation of variation in the firms' performances (ROE). Thus, we reject the null hypothesis. Yet, the model explains relatively small portion of the total variation in explaining $\mathrm{ROE}$ $\left(\mathrm{R}^{2}=0.2992\right)$. It tells us that there are other factors that would significantly contribute to the explanation of variation in ROE. However, the main goal of this analysis is not to figure out the factors and/or variables that would explain ROE. The goal is to find out 


\section{Table 3: ANOVA Table}

\begin{tabular}{|l|l|l|l|l|l|l|l|l|}
\hline Source & SS & df & MS & F & FCritical & \multicolumn{2}{|l|}{-value } & \multicolumn{2}{|l|}{} \\
\hline Regn. & 0.401123 & 3 & 0.133708 & 13.518 & 2.7004 & 0.0000 & $s$ & 0.0995 \\
\hline Error & 0.939631 & 95 & 0.009891 & & & & & \\
\hline Total & 1.340754 & 98 & 0.013681 & $\mathbf{R}^{\mathbf{2}}$ & 0.2992 & & Adjusted $\mathbf{R}^{\mathbf{2}}$ & 0.277 \\
\hline
\end{tabular}

\begin{tabular}{|l|l|l|l|l|}
\hline \multicolumn{5}{|c|}{ Table 4:Coefficients and Other Statistics } \\
\hline Intercept & Intercept & SR & Ln Asset & Sector \\
\hline B & -0.24087 & 0.245297 & 0.011319 & -0.01251 \\
\hline s(b) & 0.088766 & 0.06387 & 0.003578 & 0.003257 \\
\hline T & -2.71355 & 3.840576 & 3.163329 & -3.84068 \\
\hline p-value & 0.0079 & 0.0002 & 0.0021 & $0.00 \quad 02$ \\
\hline \multicolumn{5}{|l|}{} \\
\hline VIF & 1.0121 & 1.0082 & 1.0059 \\
\hline Durbin-Watson, d & 1.995875 & & \\
\hline
\end{tabular}

whether the diversification affects a firm's performance in Turkey -an emerging market. Thus, the low level of $\mathrm{R}^{2}$ does not decrease the quality or the validity of the model. The model is appropriate to test our hypothesis.

A close look at the effects of diversification level on firms' performances shows that the higher the SR value (which implies less diversification), the higher the performance of the firm (see Table 3). The results show that the performance of a firm improves as the level of diversification decreases, or vice-versa. More clearly stated, undiversified and/or concentrically diversified firms perform better in Turkish market than the highly diversified firms. As opposed to the findings of the emerging markets' literature, it is a similar behavior to that of the developed markets rather than the emerging ones. This might be an early signal of structural change in Turkish market. We wanted to test our hypothesis by using the data before and after the year 2000, and compare the results to see whether the they signal any structural change in the market. Unfortunately, we were unable to test it due to the lack of data. The authors will continue their efforts to gather the data and check into the structural change, if any, of the Turkish market.

Size and industry affiliation also affect firms' performances. The results indicate that as size gets larger companies perform better in Turkey. This might be due to the better utilization of the performanceenhancing tools and management practices in larger firms, such as technology transfer, continuous improvement efforts, strategic management practices, etc... However, all those claims need to be tested.

\section{SUMMARY AND CONCLUSIONS}

It is believed that the less diversified firms perform better than the highly diversified ones for the developed countries or markets. It is also believed that the diversified firms would perform better in emerging markets. This paper tests whether the latter belief holds true for Turkey, which is also an emerging market. The hypothesis was tested by employing the regression analysis method. It is used to test the general relationships between the firm's performances and the measures of diversification, size, and the industry affiliation.

The findings indicate that the research model is statistically significant. Coefficients of the independent variables significantly contribute to the explanation of variation in firms' performances. We finally reject our null hypothesis based upon the statistical findings.

Contrary to the findings of literature on emerging markets, the results of this research indicate that Turkish market differs from its counterparts when it comes to the differentiation strategies. The results show that undiversified and/or less diversified Turkish firms perform better than the highly diversified firms, as it is the pattern in developed markets. The authors believe that this might be an early indication or sign of structural change in Turkish market.

Results of the analysis prove that the high diversification strategies do not significantly contribute to the profitability of the companies. Recently, the larger companies in Turkish market started to diversify around their core businesses. Further research is needed to see whether this trend supports the claims of getting "early signals of structural change" in Turkish market. Enhancing the model by incorporating data with larger sample sizes for coming years will rectify the validity of the research findings. 


\section{REFERENCES}

Alhorr, Hadi S. (2005), "Diversification and Performance: Attempting to Assess Validity," White Paper, Drake Univerisity, College of Business Administration, Des Moines, IA.

Baysinger, Barry and R. E. Hoskisson (1989), "Diversification strategy and R\&D intensity in multiproduct firms" Academy of Management Journal, 32, pp. 310- 332.

Bettis, R.A. and W.K. Hall (1982), "Diversification Strategy, Accounting Determined Risk, and Accounting Determined Return," Academy of Management Journal 25, pp. 251-264.

Brealey, Richard A. and Stewart C. Myers (1996), Principles of Corporate Finance, 5th Edition, New York, NY: McGraw Hill Publishing Co.

Bromily, P. (1986), Corporate Capital Investment: A Behavioral Approach, New York, NY, Cambridge University Press.

Christensen, H.K. and C.A. Montgomery (1981), "Corporate Economic Performance: Diversification Strategy versus Market Structure," Strategic

Management Journal 2, pp. 327-347.

Datta, Deepak K., Nandini Rajagopalan, and Abdul M. A. Rasheed (1981), "Diversification and Performance: Critical Review and Future Directions," Journal of Management Studies 28, pp. 529-558.

Eren, Erol, Stratejik Yönetim ve İşletme Politikası (2005), Genişletilmiş 7.Baskı, Beta Basım Yayım Dağıtım A.Ş., (Beta Yayınevi), pp. 221-232.

Grant, R., A. Jammine, and H. Thomas (1988), "Diversity, diversification, and profitability among British manufacturing companies," 1972-1984, Academy of Management Journal, 31, 4, pp. 771-801.

Hall, Ernest H. (1995), "'Corporate Diversification and Performance: An Investigation of Causality," Australian Journal of Management, 20, 1, pp. 25-42.

Harrison, J. S., C. H. St. John (2002), "Foundations in Strategic Management," South-Western, pp.7690.

Hoskisson, Robert E. and Michael A. Hitt (1990),
"Antecedents and Performance Outcomes of Diversification: A Review and Critique of Theoretical Perspectives," Journal of Management, Vol. 16, No. 2, pp. 461-509.

Jacobson, R. (1987), The validity of ROI as a measure of business performance, American Economic Review, 77, 3, pp. 470-478.

Jahera, John, Jr., William P. Lloyd, and Daniel E. Page (1987), "Firm Diversification and Financial

Performance," Quarterly Review of Economics and Business, Vol. 27, No. 1, pp. 51-62.

Keats, Barbara W. (1990), "Diversification and Business Economic Performance Revisited: Issues of Measurement and Causality," Journal of Management 16, No. 1, pp. 61-72.

Kerin, Roger, Vijay Mahajan and P. Rajan Varadarajan (1990), "Contemporary Perspectives on Strategic Market Planning," Boston, MA: Allyn and Bacon.

Khanna, Tarun, Krishna Palepu (1997), "Why Focused Strategies May Be Wrong for Emerging Markets," Harvard Business Review.

King, B. (1966), "Market and Industry Factors in Stock Price Movements", Journal of Business, Vol 39, pp. 139-190.

Lamont, B.T. and Anderson, Carl A. (1985), "Mode of Corporate Diversification and Economic Performance," Academy of Management Journal 28, pp. 926-934.

Long, W.F. and D.J. Ravenscraft (1984), "The misuse of accounting rates of return: comment," American Economic Review, 74, 3, pp. 494-501.

Lubatkin, M. and H. O'Neil (1987), "Merger Strategies and Capital Market Risk," Academy of Management Journal 30, pp. 665-684.

Lubatkin, M. and R.C. Rogers (1989), "Diversification, systematic risk and shareholder return: a capital market extension of Rumelt's 1974 study," Academy of Management Journal, 32, 2, pp. 454-465.

Markides, C.C. (1992), "Consequences of Corporate Refocusing: Ex Ante Evidence," Academy of Management Journal 35, pp. 398-412.

Michel, Allen and Israel Shaked (1984), "Does 
Business Diversification Affect Performance?" Financial Management, Vol. 13, pp. 18-25.

Montgomery, C.A. (1985), "Product Market Diversification and Market Power," Academy of Management Journal 28, pp. 789-798.

Nayyar, P.R. (1993), "Stock Market Reactions to Related Diversification Moves By Service Firms Seeking Benefits From Information Asymmetry and Economics of Scope," 14, pp. 569-591.

Normann, R. (1984), "Service Management: Strategy and Leadership in Service Business," Chichester (West Sussex); New York: Wiley.

Palepu, K. (1985), "Diversification, Profit Performance, and the Entropy Measure," Strategic Management Journal 6, pp. 239-255.

Palich, Leslie E., Laura B. Cardinal and C. Chet Miller (2000) "Curvilinearity in the DiversificationPerformance Linkage: An Examination of Over Three Decades of Research", Strategic Management Journal, 21, pp.155-174.

Pandya, Anil M., Narender V. Rao (1998), "Diversification and Firm Performance: An Empirical Evaluation," Journal of Financial and Strategic Decisions, 11, 2, pp. 67-81.

Prahalad, C.K and R.A. Bettis (1986), "The Dominant Logic: A New Linkage between Diversity and Performance," Strategic Management Journal 10, pp. 523-552.

Ramanujam, Vasudevan and P. Varadarajan (1990)," Research on corporate diversification : A synthesis", Strategic Management Journal, 10, pp.523-551.

Rumelt, Richard P. (1982), "Diversification Strategy and Profitability," Strategic Management Journal 3, pp. 359-369.

Rumelt, Richard P.(1986), Strategy, Structure, and Economic Performance, (Rev. ed.), Boston, MA: Harvard Business School Press.

Shaikh, Abdul Karim and P. Rajan Varadarajan (1984), "Measuring Firm Diversity: A Review and Synthesis," in R.W. Belk et al., (eds.) 1984 AMA Educators' Conference Proceedings, Chicago: American Marketing Association, pp. 185- 189.
Simmonds, Paul. G (1990), "The Combined Diversification Breadth and Mode Dimensions and the Performance of Large Diversified Firms," Strategic Management Journal 11, pp. 399-410.

Thompson, Arthur A., A. J. Strickland III, J. E. Gamble (2007), Crafting and Executing Strategy: The Quest for Competitive Advantage, $15^{\text {th }}$ Ed., McGraw-HillIrwin, New York, NY, pp.269-299.

Varadarajan, P.R. and Ramanujan V. (1990), "The Corporate Performance Conundrum: A Synthesis of Contemporary Views and an Extension," Journal of Management Studies 27, pp. 463-483.

Weston, J.F. and S.K. Mansinghka (1971), "Tests of the Efficiency Performance of Conglomerate Firms," Journal of Finance, 26, 4, pp. 919-936.

Wheelen, Thomas L., J. D., Hunger (2006), Strategic Management and Business Policy: Concepts and Cases, $10^{\text {th }}$ Ed., Pearson-Prentice Hall, Upper Saddle River, NJ, pp. 164-171. 